\title{
Developing material for English for Holiday program
}

\author{
Soviyah a,1,*, Nur Fatimah ${ }^{\mathrm{b}, 2}$ \\ a, b Universitas Ahmad Dahlan, Jalan Jend. Ahmad Yani (Ringroad Selatan), Tamanan, Banguntapan, Bantul, Daerah Istimewa Yogyakarta, Indonesia \\ ${ }^{1}$ soviyah@pbi.uad.ac.id *; ${ }^{2}$ nur.fatimah@pbi.uad.ac.id \\ * corresponding author
}

\section{ARTICLE INFO}

Article history

Received 15 October 2021

Revised 06 December 2021

Accepted 30 December 2021

Keywords

English for Holiday (EFH)

teaching English to Young Learners

(TEYL)

Research and Development (R n D)

\section{ABSTRACT}

An English program like English For Holiday (EFH), is concerned with helping children to learn English. In relation to English Education Department of Universitas Ahmad Dahlan, the department has employed an EFH program to help children with English learning during their school break. To accomplish the continuous improvement of the program, it needs research related to it, as these kinds of research provides meaningful data and product, which are important for the improvement of the program's quality. Generally, the ultimate aim of the research is to contribute to the establishment of a better EFH program, especially of English Education Department, Universitas Ahmad Dahlan. Specifically, this research aims to develop syllabus and material for EFH program of EED UAD. This research started in May and was complete in November 2020 at English Education Department of Universitas Ahmad Dahlan (UAD). It utilized Research and Development (R\&D) type with ADDIE model initiated by McGriff (2000) which endeavors a development process encompassing five major stages i.e., analyze, design, develop, implement, and evaluation. The research results show that the EFH material is developed to fulfil the children's needs of material for EFH program. The developed product offers an alternative solution to fill the children's needs. Based on the evaluation, it is found out that the developed material is considered very good. Through this material, children participating in EFH program can learn English in an enjoyable way. Although the major target is to improve children's speaking skill, through this material, children can learn and develop their other skills i.e., listening reading and writing as the developed material is written in an integrated way involving all four skills of English.

This is an open access article under the CC-BY-SA license.

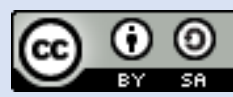

How to Cite: Soviyah \& Fatimah, N. (2021). Developing material for English for Holiday program. English Language Teaching Educational Journal, 4(3), pp. 235-250.

\section{Introduction}

In Indonesia, English as a foreign language has been introduced to elementary school students as one of the subjects they study. This policy is in line with the statement of the Regulation of the Government of the Republic of Indonesia number 32 the year 2013 about the modification of the Government Regulation number 19 the year 2005 about National Standard of Education stating that English as a foreign language becomes one of three languages to be taught in schools because it is imperative in global relationships. However, through the Regulation of the Republic of Indonesia number 21 the year 2016 about primary and middle/secondary education, the Republic of Indonesia's minister removed English from the list of elementary school main subjects. Hence, English is no longer a local content subject at the elementary school level. Instead, it is offered as an extracurricular subject. It suggests that English language learning for young learners is still considered necessary.

In practice, since English is removed as a local content subject at the elementary school level, young learners are likely to have little English learning access. Moreover, the learning time in school 
is also limited. Therefore, in many cases, parents of the young learners would send their children to private English courses, hire private teachers to teach them English, or send them to various out of school English programs such as English for holiday (EFH), summer camp, English camp, summer coursework, and so on. These programs are specifically designed to facilitate learners in learning.

In regards to these specially designed English programs, many researches claim on the advantages of them towards the children' s development. Summer camp, for example, is quite popular among parents and children. It is widely used and found to garner many benefits in different areas such as computer science, psychology (Adams \& Savahl, 2017; Collado, Corraliza, Staats, \& Ruiz, 2015), languages (Lee \& Curran, 2009; Melhuish, ,Ereky-Stevens, Petrogiannis, Ariescu, Penderi, Rentzou \& Leseman, 2015; Bus, Takacs \& Kegel, 2015; Bialystok, 2018) and other areas (Brusseau, Hannon \& Burns, 2016); He, Xiang, Zeng, Mai, Chen, Zhang \& Morgan, 2015; McCoy, et.al., 2017).

Zooming into English learning context, language programs like English for holiday and language summer camp are known to be beneficial in contributing to the children's development has long been acknowledged. Based on the existing research, many outside of school language programs such as English for holiday and other programs of the kind are identified to be able to provide rich contexts for learning and development (e.g, Garst, Browne, \& Bialeschki, 2011). These programs are reported to contribute not only to children's language aspect but also their psychological aspect. Testimonies from those attend the program report that they experience powerful, even life changing experiences (Anghel, Cabrales, \& Carro, 2016). Moreover, these programs are frequently described as setting for social- emotional learning (e.g., Wilson \& Sibthorp, 2018) and even some researches often report such children's and youth prominent development aspects are found out to be listed among the program outcomes as friendship skills, relationship building, and working with others (Sepúlveda \& Hutton, 2019).

In relation to English Language Teaching (ELT) context, English for holiday and summer camp programs that are designed to enhance students' knowledge and confidence in using the language is considered a quite novel way among researchers in ELT field. Among many researches in the field, the study conducted by Rugasken and Harris (2009) could serve as an example. This research revealed the results that children joining English summer program has been observed to able to help them achieve the goal for them to gain knowledge of the English language and acquire confidence in their speaking skills, with an additional benefit for participants (both children and instructors) to develop a deeper appreciation of the people and the new culture to which they were exposed to.

In addition to the research, in sum, many other researches in the field agree that English for holiday and summer camp programs are beneficial in developing children's English mastery because they are able to break the resistance the children usually experience when learning a new language and to provide a casual setting for communicative learning experiences to take place. Thus, it's just acceptable to state that children can get much benefits from out of school programs such as English for holiday and language summer camps as the process they provide them make them able to appreciate and enjoy a fun learning experience within a short duration rather than formal, traditional, instruction-based classroom settings.

With these considerations in mind, the researchers, who made up the material for English for Holiday Program, set out to achieve similar goals in designing the materials that fit the goals and elements of learning English as a foreign language.

Universitas Ahmad Dahlan (UAD) is one of the private universities in Yogyakarta Indonesia. One of the faculties it houses is faculty of education and teacher training in which English Education Department becomes a part of. English Education Department has been tasked with designing a short English program intended for children. This was initiated in 2010 under the name of English for Smart Holiday and continually conducted in 2019 using UADventure Program as its name. Practically the program is conducted during school summer break as a non-formal English learning for children aged between 7 to 12 years old. The program's participants learned inside the classroom and outside the classroom, such as campus library, observatory, and other areas of the campus. The program offers a fun way of English learning with possibly much less pressure as compared to the regular learning inside classrooms. This program usually lasts 6 days. It starts at 08.00 a.m. and ends at 16.00 p.m. This program's agendas are various, starting with English learning (listening, speaking, reading, and writing), cooking class, market day, library visit, observatory visit, and class performance. So far, the 
program has received positive feedback from those involved, such as the teachers, the learners, the parents of the learners, the executives, the department, and the university itself. Moreover, they wish that there would be a similar program to be held regularly in the future.

Based on the early observation, the chief executive of the program said that with lots of enthusiasts, various activities, and positive feedback from those involved, the program has a chance to be held annually. However, there were some areas of the program that need to be improved, still. One of them was the absence of a fixed syllabus and ready-for-use materials. This was acknowledged by some teachers involved in the last program. They said that in spite of the fact that the lessons were always enjoyable and engaging for the children there were not a syllabus and ready-for-use materials yet. As a result, the teachers felt overwhelmed because they had to prepare the learning guideline and the possible materials in a short time. Therefore, some aspects of the program need to be improved. The purpose of the improvement is to increase the program's quality so that the learning process can be more meaningful and engaging. The aspects meant are the syllabus and the materials. Therefore, the primary purpose of this research is developing syllabus and materials for $\mathrm{EFH}$ program. The ultimate aim of the research is to contribute to the establishment of the better EFH program, especially of English Education department, Universitas Ahmad Dahlan.

\section{Method}

This research started from May 2020 and was complete in November 2020 at English Education Department of Universitas Ahmad Dahlan (UAD). It utilized Research and Development (R\&D) type with ADDIE model initiated by McGriff (2000) as it endeavored to develop material for English for Holiday Program. The development process encompassed five stages i.e. analyze, design, develop, implement, and evaluation as depicted in Figure 1:

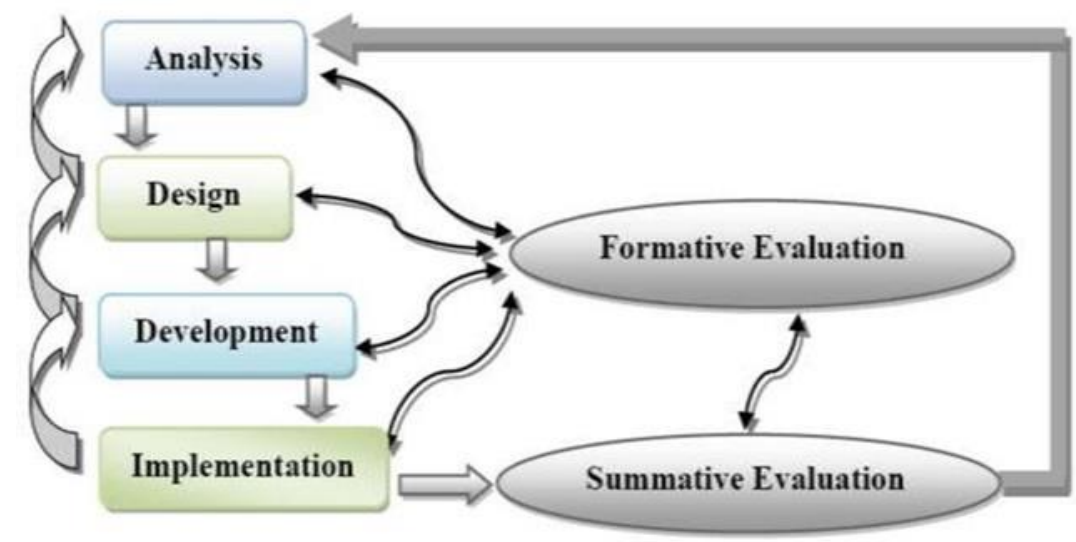

Figure 1. Development process of English for Holiday

As for the analyze stage, the researchers used surveys and interviews proposed as data collection techniques (Rahman, 2015; Ramírez, 2015). In collecting the data, the researcher used two instruments, namely questionnaire and interview guidance and involved 30 parents of the EFH participants last year. In addition, it also invited some related parties such as teachers, English teachers of primary school, program coordinator, and head of English Department UAD. Table 1 displays the detailed information regarding instruments and subjects of the need analysis stage. 
Table 1. Instrument of Data Collection

\begin{tabular}{|c|c|c|}
\hline Instruments & Descriptions and Aims & Subjects \\
\hline Questionnaire & $\begin{array}{l}\text { It contains } 46 \text { closed-form questions and uses the Likert } \\
\text { scale with four alternative answers: strongly agree (4), agree } \\
\text { (3), disagree (2), and strongly disagree (1). It is to collect } \\
\text { quantitative data (main data). }\end{array}$ & $\begin{array}{l}30 \text { parents of the EFH } \\
\text { children }\end{array}$ \\
\hline $\begin{array}{l}\text { Interview } \\
\text { Guidance }\end{array}$ & $\begin{array}{l}\text { It contains } 13 \text { open=ended questions. It is to collect } \\
\text { quantitative data (supporting data). }\end{array}$ & $\begin{array}{l}\text { EFH program's teachers } \\
\text { and coordinators, teacher } \\
\text { of elementary school. } \\
\text { The head of English } \\
\text { Education Department of } \\
\text { UAD. }\end{array}$ \\
\hline
\end{tabular}

The questionnaire was used to collect the main data related to target needs and learning needs of the EFH program participants. The target needs included necessities, lacks, and wants, whereas the learning needs included learning style, media, and activities. To support the main data, the researchers asked 13 open-ended questions listed in the interview guidance to the subjects. The organization of the questionnaire is presented in the Table 2.

Table 2. Organization of the Questionnaire

\begin{tabular}{lcl}
\hline \multicolumn{1}{c}{ Aspect } & Item & \multicolumn{1}{c}{ Aim } \\
\hline Necessities & $1-20$ & $\begin{array}{l}\text { To analyze purposes of joining EFH program } \\
\text { and learning English } \\
\text { To analyze the children's level of English proficiency }\end{array}$ \\
Lacks & $21-23$ & $\begin{array}{l}\text { To analyze topics that want to be learned } \\
\text { Wants }\end{array}$ \\
$\begin{array}{l}\text { Learning style } \\
\text { Media }\end{array}$ & $34-37$ & $\begin{array}{l}\text { To analyze the children's learning style } \\
\text { To analyze media that should be included in the } \\
\text { materials } \\
\text { To analyze activities that should be included in the } \\
\text { materials } \\
\text { To analyze assessment that should be implemented }\end{array}$ \\
Astivities & $41-43$. & \\
\hline
\end{tabular}

The data obtained from the questionnaire were analyzed quantitatively using a calculation model (Patten, 2016; Curle \& Derakhshan, 2021). The researchers analyzed the data by frequency and processed the data by calculating the mean score. Then, the data were presented using tables in percentages and interpreted in the form of paragraphs. In addition, an open-ended interview was used as the supporting data to strengthen the quantitative data. The supporting data were analyzed using a qualitative approach (Miles, Huberman, 2020; Creswell, 2012; Creswell, 2014). Finally, the supporting quotes from each participant were listed and discussed.

Meanwhile, for evaluation stage, a Focused Group Discussion (FGD) was conducted to evaluate the developed product. The discussion involved English teachers of elementary schools in Yogyakarta, lecturers of English Education Department and Primary School Education Department $(P G S D)$, EFH coordinator as well as the head English Education Department of UAD. 


\section{Findings and Discussion}

\subsection{Analyze Stage}

1) EFH Children's Target Needs

The analysis of the target needs is divided into three points; necessities, wants, and lacks.

\section{Necessity}

In this part of the analysis, there were 20 questions related to the children's necessities. The questions include the purposes of joining the EFH program and the goals of learning English.

In terms of purposes of joining the EFH program, the results showed that respondents strongly agreed that their children could master English was the reason they participated in the EFH program (89\%). The respondents also strongly agreed that their children participated in the EFH program because they like to learn English (90\%). Furthermore, respondents strongly agreed that their children participated in the EFH program because they want to spend their time on holiday (91\%), and the respondents did not agree that the purpose of their children participated in the EFH program was because of their friends (56\%). These data were supported by the result of the interviews. Here are some results of the interview on the respondent.

RI3: "They will understand more about English, not only about speaking, but also about how to write, how to read, and how to listen. Besides, through the program, the children can add friends and spend their spare time on holiday."

RI4: "In order to know about English related to vocabulary and also to spend the spare time on holiday."

Regarding the purpose of learning English, the results showed that respondents strongly agreed (90\%) that the children were able to learn the four skills of English, which are listening, speaking, reading, and writing, and be able to get the sub skills under each of these four skills. These data were supported by the result of the interviews. Here are some results of the interview with the respondents:

RI2: "In my opinion, if they can learn listen in English lesson and get used to it, they will learn how people speak, pronounce, and then they can imitate what they learn."

RI5: "They can communicate with correct pronunciation, or when they use expressions, they are not nervous and doing only little mistakes."

RI1: "For the reading, it is about understanding the texts. They can also get vocabularies from the texts especially simple texts."

RI2: "In my opinion, the highest skill of English skills is writing skill because they have to construct a word to make a sentence in correct tenses. The sentence should be correct and easy to hear. When the children understand how to write, they are in the final stage of learning English. So, in essence they will certainly add vocabulary and practice what they already understand."

\section{Lacks}

'Lacks' is the gap between what children have already known and what they have not known (Hutchinson \& Waters 1987; Brown, 2016). From the questionnaire distributed, it can be summarized that most of the respondents said that the children were at the beginner level (83\%). Some children were at the intermediate level (57\%) and only a few children were at the advanced level (42\%).

\section{Wants}

'Wants' cover what children want to know (Hutchinson \& Waters 1987; Hyland, 2019). The data showed that the respondents stated the children wanted to learn English through the topic of school $3.50 / 88 \%$, the topic of living creatures $(87 \%)$, the topic of space $(85 \%)$, the topic of food and drink (89\%), the topic of transportation (86\%), the topic of social (93\%), the topic of public places (93\%), the topic of technology (88\%), the topic of dream job (93\%), the topic of basic concept (89\%), the 
topic of introduction (88\%). These data were supported by the result of the interviews. Here are some results of the interview on the respondent.

RI7: "The children in learning English may need the topics, but the dictions to name the topics should be considered so that the children understand the topics, then the order of the topics should be appropriate with their level of difficulty.

\section{2) Children Learning Needs}

The learning needs are related to what students need to learn (Hutchinson \& Waters, 1987; Brown, 2016; Hyland, 2019). The analysis was focused on learning styles, media, and activities.

From the result of the questionnaire, it can be seen that most of the children tended to learn English using the visual learning style (85\%). Some of them tended to learn with an auditory style (80\%), and others tended to learn English using the kinesthetic learning style (81\%). The questionnaire's results showed that the respondents stated that they wanted their children to learn using visual-based media because the visual-based media was suitable for their children $(86 \%)$. The other respondents also agreed that audiovisual-based media $(85 \%)$ and authentic and real media $(84 \%)$ were suitable for learning English. These data were supported by the result of the interviews.

RI7: "Now, the trend is multi-model. It means that the media is not only from visual sources but also audio and audiovisual sources, so maybe all of the sources need to be combined."

Further, the result showed that the respondents stated that they wanted their children to learn English through direct practice activities while learning English (91\%). They also wanted their children to learn by playing/gaming activities (85\%), and drawing, singing, moving, and singing activities $(84 \%)$. These data were supported by the result of the interviews. The following is a quotation of transcriptions of interviews with (RI7):

RI7: "The basics of developing the four skills, in my opinion, is vocabulary. The richer the vocabulary that the children have, the easier it is for them to speak, write, and understand any written and oral texts printed in English."

\subsection{Syllabus Development}

After the data on the children's needs were collected and analyzed, the process was taken further into syllabus development process. In developing the syllabus, it was developed taking topic based syllabus type (Rangel \& Pernett, 2020; Knezović, 2016). The following explanation presents the description of the designed syllabus.

\section{General Consideration}

The results of the need analysis revealed that the children were group of young learners (7-12 years old). The results also revealed that, mostly, they were in beginner level of English. Related to grammar complexity, the children were expected to learn to use expressions in English conversationand use more complex word forms. While related to the vocabulary, the children were expected to learn vocabulary related to their daily life.

\section{Topics}

The topics included in the designed syllabus were social, public places, dream jobs, food and drink, base concept, and introduction. These topics provided information on what language target, knowledge of grammar and vocabulary were needed to be taught and practiced.

\section{English Skills}

Based on the need analysis, children wanted to be able to respond in English when they were asked about their name or their friend's name, description of their families or friends, their future intentions, 
and directions to go to some places. They also wanted to be able to speak in English when they ask someone's name, describe a friend, name objects, buy food and drinks, talk about future intentions, and give directions.

\section{Learning Media and Activities}

From the needs analysis, it is found out that visual-based media and hands- on practice activities had the highest mean score. Therefore, the expected material should be more emphasized on these kinds of activities.

In light of the result of the need analysis and the theoretical framework for syllabus design, as discussed, the researchers considered a topic based syllabus as the most appropriate syllabus for the EFH program. It's because this syllabus is based on learners' communication needs and purposes for everyday social interaction. It specifies language topics, knowledge of grammar, and vocabulary that learners need for communicative tasks as well. Besides, it's usually graded to help children progress gradually at a comfortable pace. Table 3 shows the brief overview of the syllabus developed.

Table 3. English for Holiday Syllabus Topic

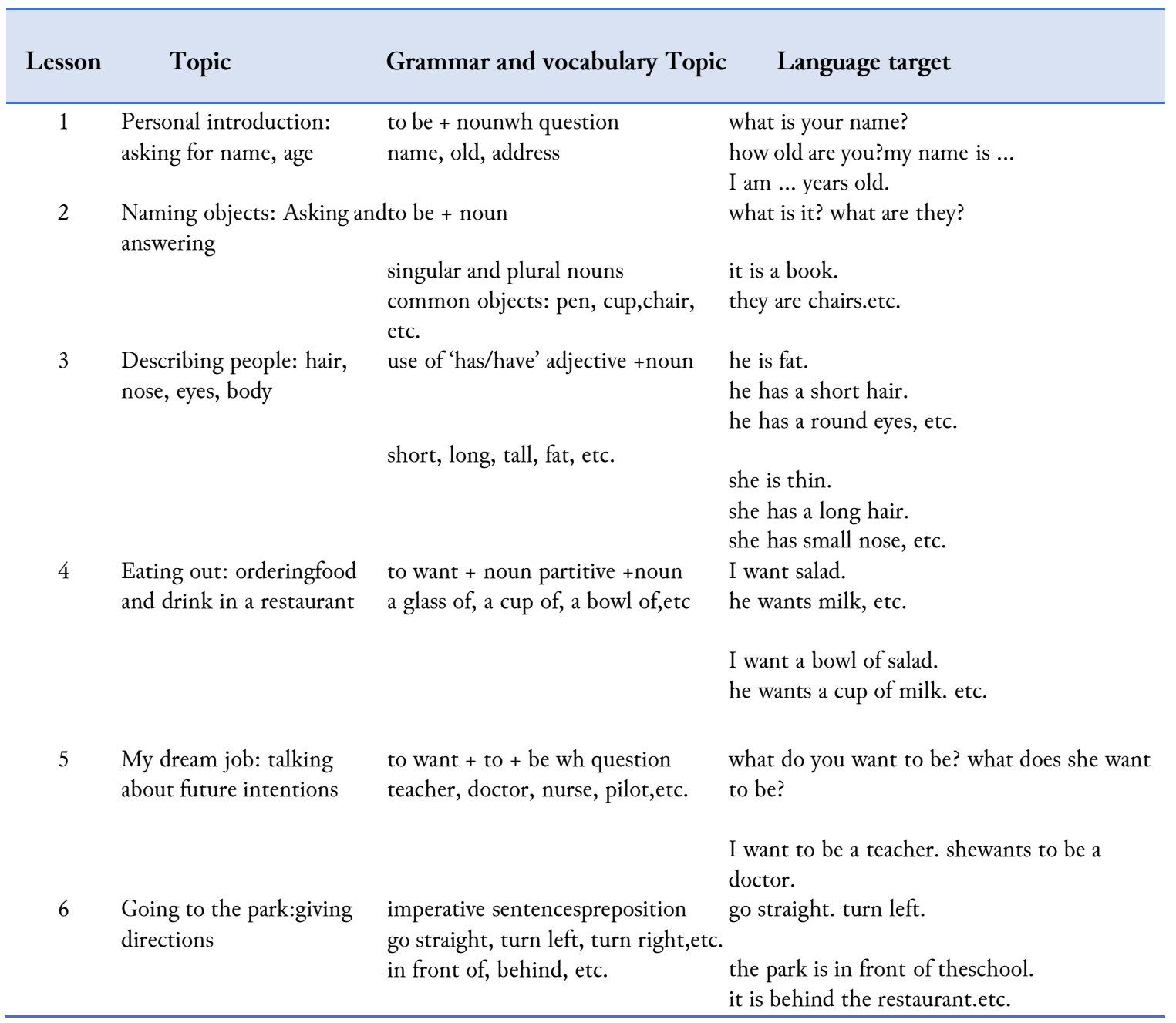

Notes: AGE: 7 - 12 years old, LEVEL: Beginner, MEETINGS: Six meetings

For the purpose of this research, due to the consideration of research feasibility, only three most chosen topics out of six listed that would be developed. The three said topics developed were social, 
public places, and occupation/jobs. Furthermore, after the topics were decided, then the syllabus was modified and made more complete as shown in Table 4.

Table 4. Details of English for Holiday Syllabus

\begin{tabular}{|c|c|c|c|c|c|}
\hline Lesson & Topic & Syllabus & $\begin{array}{l}\text { Grammar and } \\
\text { Vocabulary }\end{array}$ & Language Target & Activity \\
\hline 1 & $\begin{array}{l}\text { Social: } \\
\text { Greetings } \\
\text { someone, } \\
\text { Introduction } \\
\text { myself and } \\
\text { others }\end{array}$ & $\begin{array}{l}\text { Students are able to read } \\
\text { vocabulary/text aloud } \\
\text { correctly. } \\
\text { Students are able to identify } \\
\text { simple pictorial text. } \\
\text { Students are able to identify } \\
\text { the information in the text. } \\
\text { Students are able to } \\
\text { examine the explicit and } \\
\text { implied meaning in the text } \\
\text { related topic. } \\
\text { Students are able to } \\
\text { comprehend the text } \\
\text { related topic. }\end{array}$ & $\begin{array}{l}\text { to be + noun } \\
W+H \text { question } \\
\text { This is } \\
\text { name, old, address, } \\
\text { etc. }\end{array}$ & $\begin{array}{l}\text { Hi, Good morning } \\
\text { What is yourname? } \\
\text { How old areyou? } \\
\text { Where do you come } \\
\text { from? } \\
\text { My name is... } \\
\text { I am ... years old } \\
\text { I come from... } \\
\text { Her / his name is... }\end{array}$ & $\begin{array}{l}\text { Read the vocabulary aloud. } \\
\text { Arrange the letters into correct } \\
\text { vocabulary. } \\
\text { Complete the blank dialog/text } \\
\text { with the correct vocabulary. } \\
\text { Answer the questions with the } \\
\text { correct information based on } \\
\text { the dialog/text. } \\
\text { Circle TRUE/ FALSE the } \\
\text { correct information based } \\
\text { on the text/dialog }\end{array}$ \\
\hline 2 & $\begin{array}{l}\text { Going to the } \\
\text { park: Giving } \\
\text { directions }\end{array}$ & $\begin{array}{l}\text { Students are able to read } \\
\text { vocabulary/text aloud } \\
\text { correctly. } \\
\text { Students are able to identify } \\
\text { simple pictorial text. } \\
\text { Students are able to identify } \\
\text { the information in the text. } \\
\text { Students are able to } \\
\text { examine the explicit and } \\
\text { implied meaning in the text } \\
\text { related topic. } \\
\text { Students are able to } \\
\text { comprehend the text } \\
\text { related topic. }\end{array}$ & $\begin{array}{l}\text { imperativesentences } \\
\text { preposition } \\
\text { School, library, } \\
\text { bakery, park,etc. } \\
\text { go straight,turn } \\
\text { left, turn right, etc. } \\
\text { beside, between, } \\
\text { across from, next } \\
\text { to, etc }\end{array}$ & $\begin{array}{l}\text { Go straight } \\
\text { turn left } \\
\text { Where the school is? } \\
\text { The park is a cross } \\
\text { from the school. } \\
\text { The library is } \\
\text { between the school } \\
\text { and the bakery. }\end{array}$ & $\begin{array}{l}\text { Read the vocabulary aloud. } \\
\text { Arrange the letters into correct } \\
\text { vocabulary. } \\
\text { Complete the blank dialog/text } \\
\text { withthe correct vocabulary. } \\
\text { Answer the questions with the } \\
\text { correct information based on } \\
\text { the dialog/text. } \\
\text { Circle TRUE/ FALSE the } \\
\text { correct information based } \\
\text { on the text/dialog }\end{array}$ \\
\hline
\end{tabular}

\subsection{Design Stage}

The design stage included the process of designing the material of English for Holiday (EFH) Program. The detailed explanation of the process starts with arranging the material. Based on the data obtained in the analysis step and the decided topics, the most three topics that the children wanted to learn were Social, Public Places, and My Dream Job. The material would be arranged systematically following the levels of difficulty. Each topic had three stages; Pre - Activity, While - Activity, and Post - Activity. During pre-activity, most activities would be focused on arousing children's motivation and interest towards the topic as well as exposing them to the relevant vocabulary. This is following the procedure that pre-activity has several benefits to children, namely; providing an example to the children of the learning process in positive way, exposing the children to enrich their vocabulary, giving new information, giving the children opportunity to listen and use their imagination, and improving the skill demanded in the activity. Meanwhile, for while - activity, it would be focused on exposing the children to activities that provide them with opportunities to use the target language to achieve communicative function (Noguchi, 2019; Bao \& Du, 2015; Sholeh, 2020; Yufrizal, 2017). As for the post - activity, it would be focused on providing the children with comprehension and writing activities (Wigfield, Gladstone \& Turci, 2016). The children should examine, understand, and gain the meaning of the text as Kendeou, McMaster, and Christ (2016) stated that reading comprehension is an ability to identify those skills needed to understand and gained information contained in written materials. 
Next was selecting pictures. Based on the needs analysis results, as the material was mainly for children, it would contain a lot of pictures. For this, the researchers collected and selected pictures that were relevant to the targeted three topics. These pictures covered pictures of boys and girls, places, sceneries, landscapes, and other related ones. In selecting these pictures, the researchers did that very carefully involving making consideration of the possible theories and philosophical values underlying them. For example, in the Social topic, to introduce greeting vocabulary such as 'good morning', 'good afternoon', 'good evening', and 'good night' the researchers used a hillside picture with the sun which was located differently. As seen in Figure 2, for good morning expression it's used a picture of the situation in the morning where the sun was located in the left in yellow color, for good afternoon, the sun was located over the top of the hill in yellow color, good evening was represented by the sun which was located in the right but the color was changed to orange and good bye expression was delivered by the picture of the night situation when the sun was gone and there was only hill with the stars and the moon. This way the pictures became relevant and suitable with what the children saw in their daily life, and thus making it easy to understand.
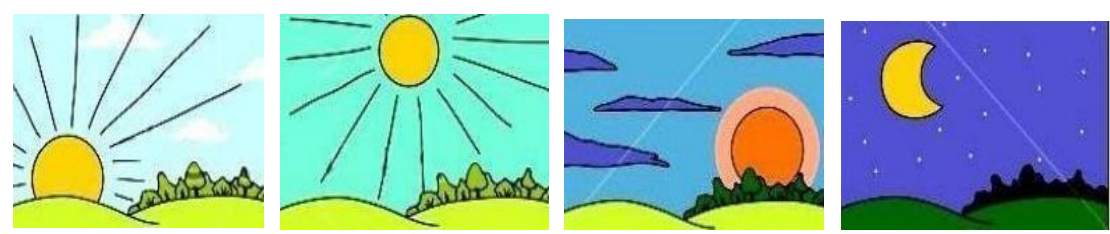

Figure 2. Relevant pictures of English for Holiday

After selecting pictures, the next activity in the design stage was making storyboard of the material. In this activity, among things designed were front cover for whole material, cover for each lesson, vocabulary section, and activity section. In addition, type and size of the font, color, header and footer and other needed aspects were also designed rigorously. Figure 3 depicts one example of the design of the cover of each of the lessons.

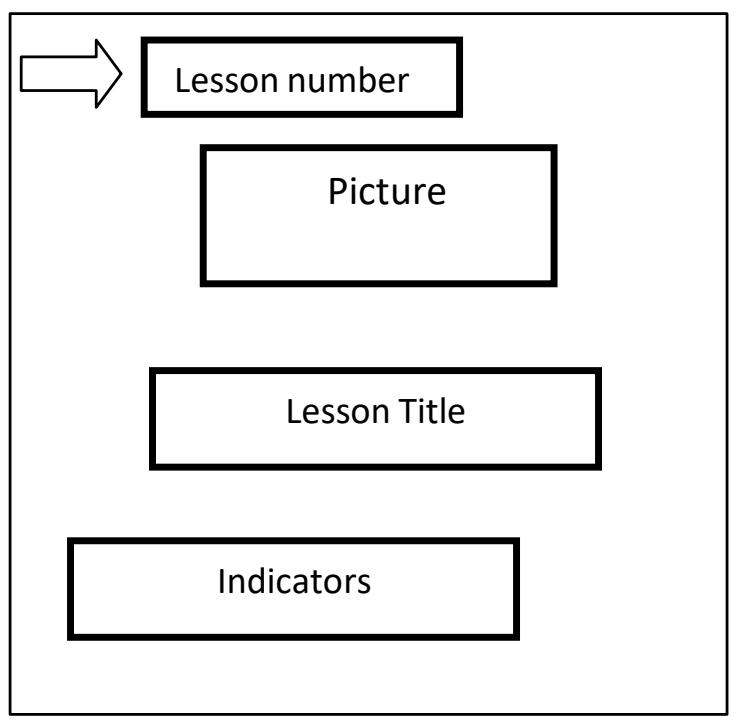

Figure 3. Design of cover of the lessons

\subsection{Develop Stage}

The third stage is the development stage. In this stage, the researchers developed the outline and story board made previously in the design stage. The first part developed was the front cover. It's simple containing the title, a picture, and the name of the author. The researchers chose the picture with the nuance of children who looked excited with a book in front of them. Figure 4 nuance complied with the whole concept of the material, i.e., fun and enjoyable learning English with friends. 


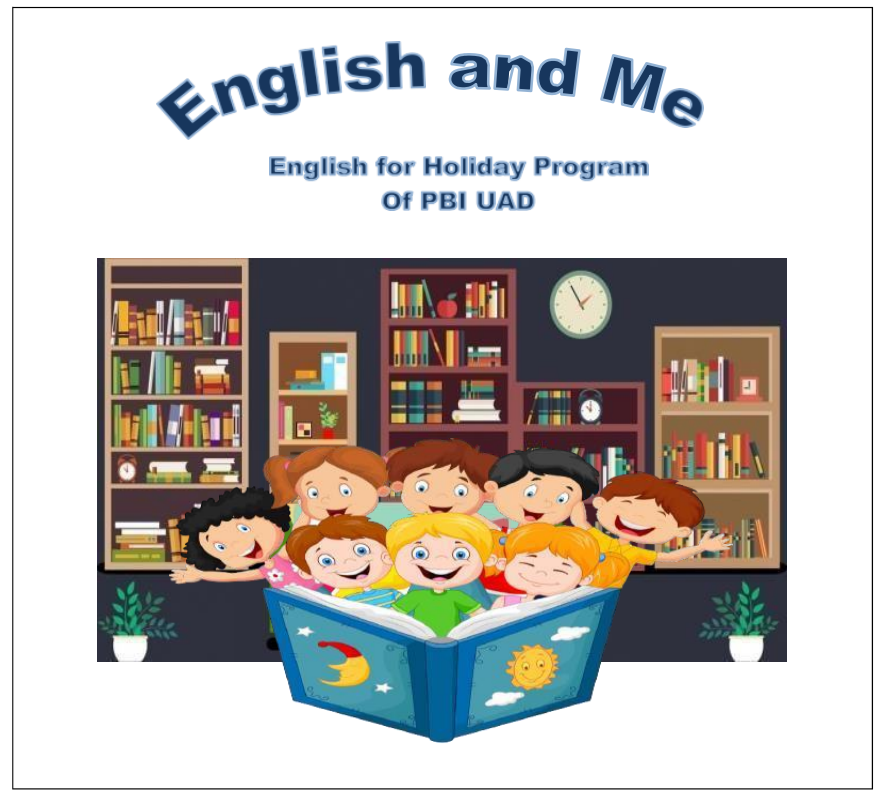

Figure 4. Realization of whole concepts of English for Holiday materials

For these two pictures in Figure 5, they are representing two sections i.e. the table of contents page and cover of lesson 1. As informed previously, as the material was for children, it was made to suit children's characteristics such as rich in visual like colorful and full of pictures. In addition, it also presented simple language. On the left is the table of content page. It presents the three topics developed i.e. Social, Public places, and Occupation/jobs. Meanwhile, the picture on the right is the cover of each lesson, in this case it's for lesson 1. For the cover of the lesson, it contained lesson number, lesson pictorial illustration, lesson title, and list of indicators. Presenting lesson number and title clearly at the beginning helps children get the point from the start, while listing the indicators set for the lesson unit will help children and their parents be informed and aware of what kind of competencies the children will get after learning the unit/topic.
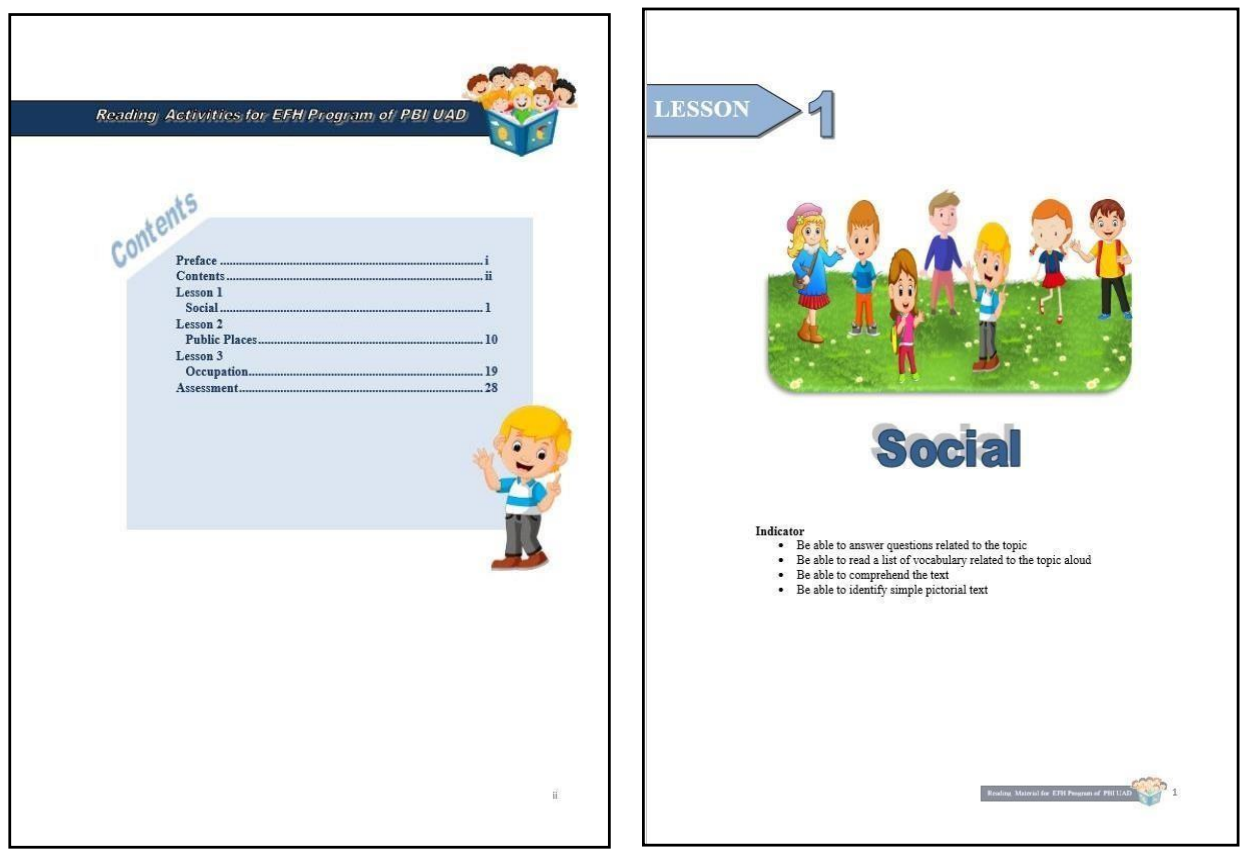

Figure 5. Realization of presentation of competencies to achieve

For the development of the activities, as explained previously, the material was developed following the level of difficulties starting from easy to difficult. Meanwhile, the activities were 
arranged from Pre-activities, While-activities, Post-activities. Other than that, the activities were also covering all four skills i.e., listening, speaking, reading, and writing. Although speaking was considered the main skill developed, other three skills got the same proportions. Furthermore, these four skills weren't presented in isolation. Instead, they're made integrated and supported one another. By so doing, it's expected that children will find this book helpful to improve their English.

The pictures in Figure 6 depict the pages of Pre-activities. The activities of Pre-activities are focused on vocabulary building. The purpose is that by being exposed to the needed vocabulary, it's expected that the children will be able to cope with the exercises and task that follow. As explained previously, the vocabulary is presented in monolingual way with no translation but there's plenty of pictures accompanied so that from these pictures, the children will be able to get the vocabulary more easily and in context.
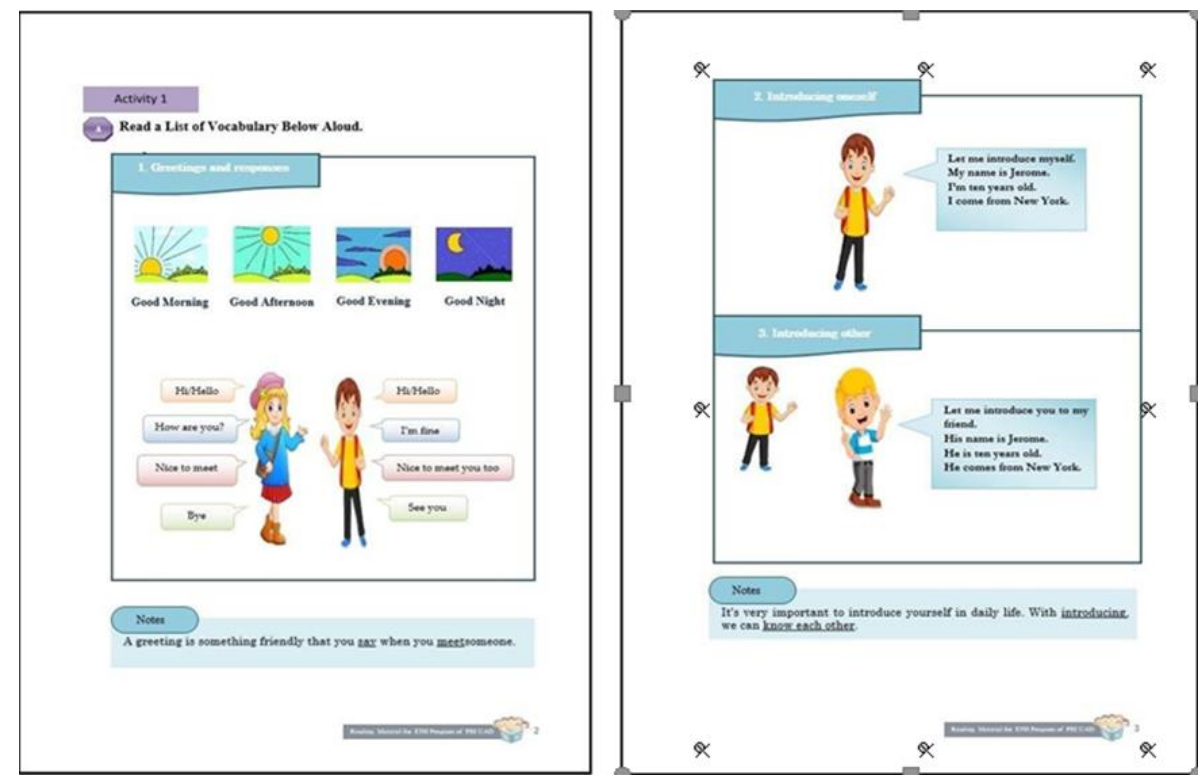

Figure 6. Presentation of monolingual materials

As for the while-activities and post-activities, the researchers developed various activities (in Figure 7) such as making simple conversation based on the given situation (top left picture), filling in the bubbles (topright picture), reading and answering orally (bottom left picture), and other activities of the kind. These activities were developed in order to improve the children's English. Interestingly, though at aglance, the activities look like they're reading activities, they're basically speaking focused. It's because in doing these activities, the children will communicate a lot with their friends. And that means they're on their journey of improving their speaking ability. Furthermore, they need to write here and there while doing these activities. Therefore, it can be said that the while-activities are developed in an integrated way integrating the four skills of English. 


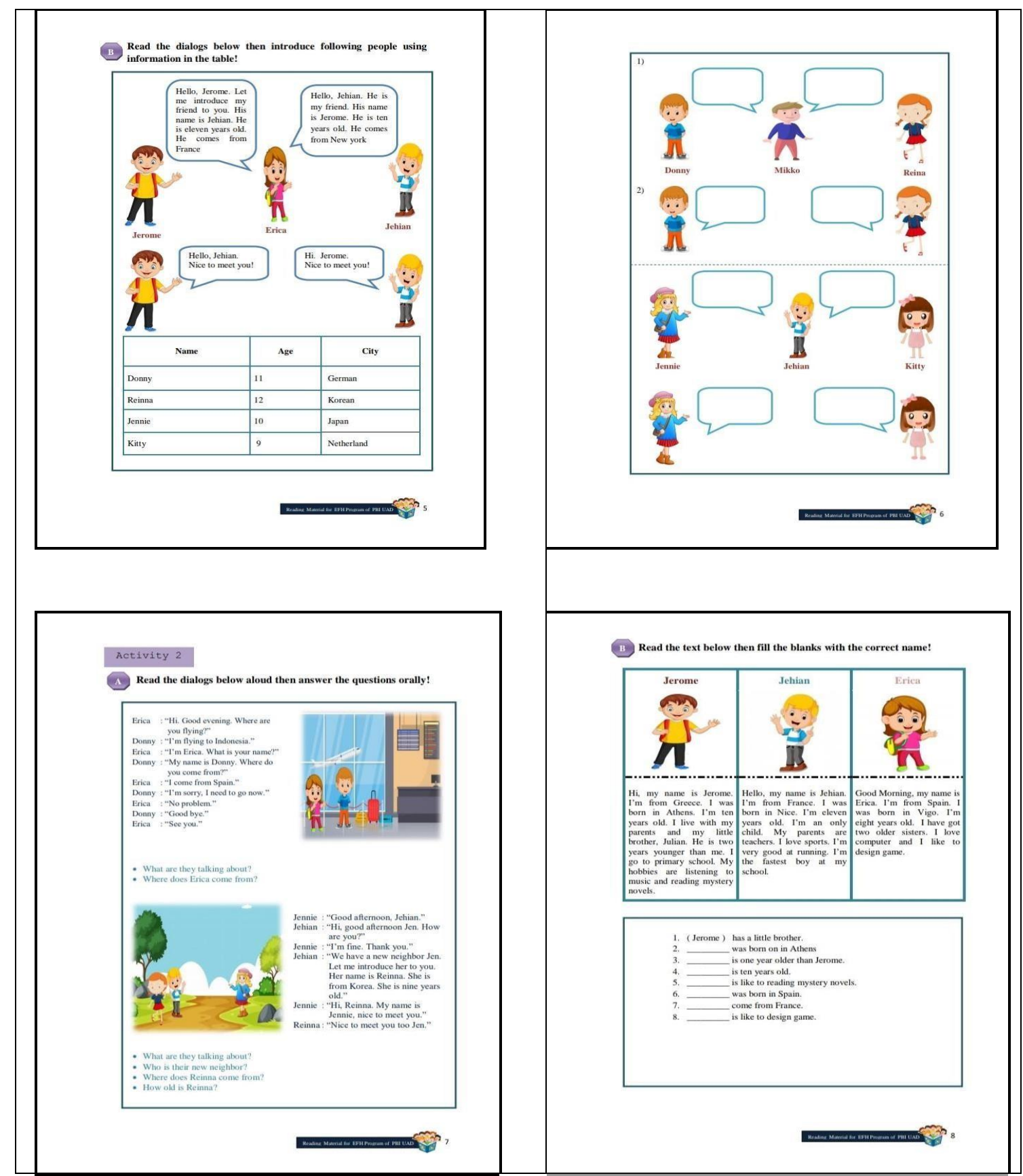

Figure 7. Activities to develop language skills

In addition to the three topics developed, the material was also completed with an evaluation section. This section was presented at the end part of three topics. It assessed all topics provided. This was meant to help children, teachers and also parents to measure the attainment of the indicators. The types of the evaluation were also various, such as word matching, true false, multiplechoice, giving short answer and some performance one. Figure 8 depicts the evaluation section. 


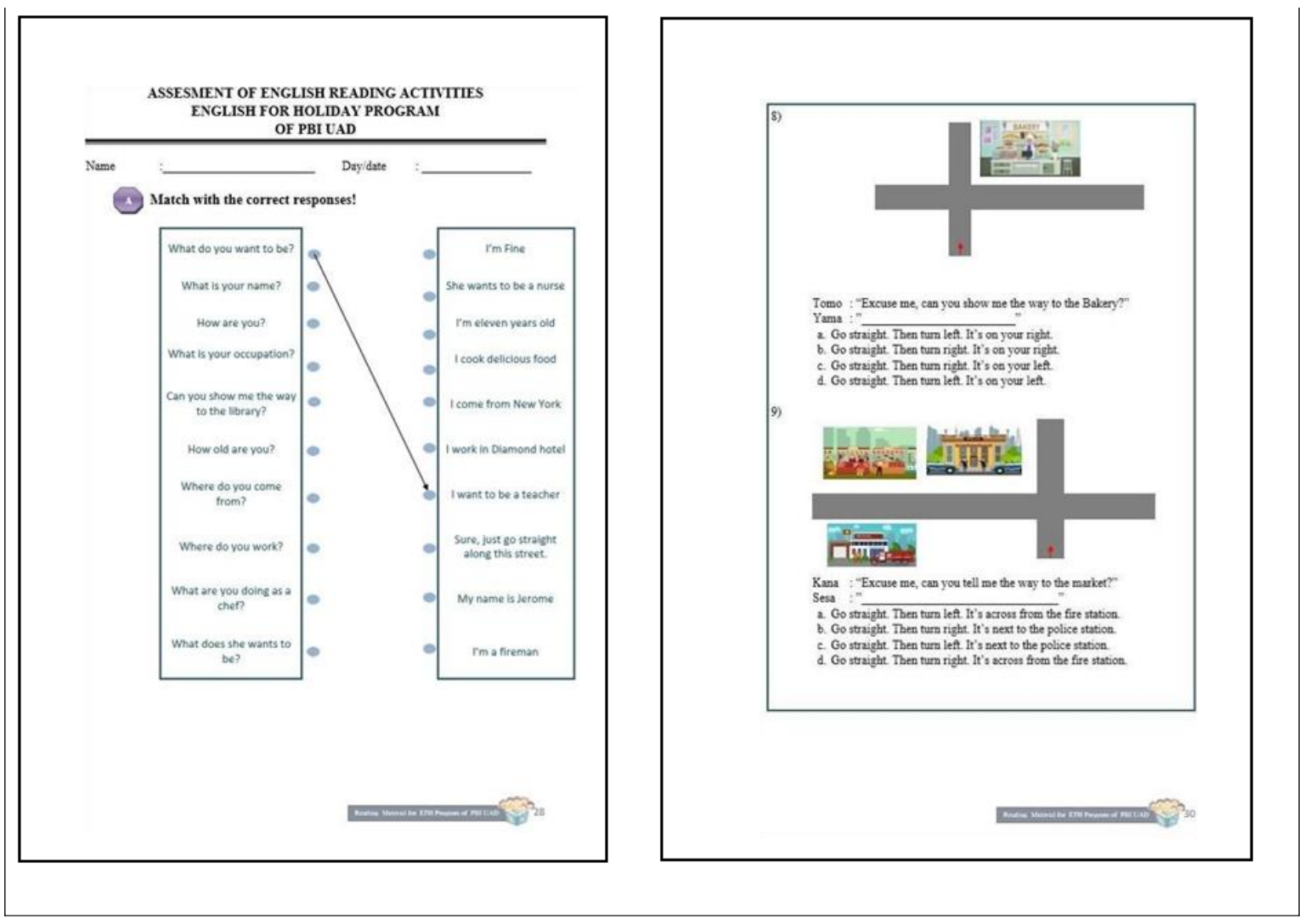

Figure 8. Evaluation sheets

\subsection{Implementation Stage}

For the implementation stage, it was originally planned to be tried out to the children participating in the EFH 2020 in July 2020 during school break when EFH 2020 program conducted. However, due to the COVID19 pandemic, this became impossible because the EFH 2020 program was canceled. Therefore, the implementation stage only involved several related parties in a Focused Group Discussion (FGD). It was conducted in beginning of November 2020. The invited parties were English teachers of some elementary schools in Yogyakarta, lecturers of English Education Department and Primary School Education Department (PGSD), EFH coordinator as well as the head English Education Department of UAD. In addition, a few representatives from parents were also invited. From this FGD, some feedback and input were obtained. The feedback was used as a basis to do revisions to the product before it's finally evaluated.

\subsection{Evaluation Stage}

For the evaluation stage, another Focus Group Discussion was held. It's conducted in Mid November 2020. It involved an expert in Teaching English to Young Learners (TEYL) field, an expert in media development field, an expert in primary education field, and a senior English teacher. The instrument used was a checklist taken from BNSP. The checklist evaluated four main aspects with the score varied from 1 to 4 indicating the level from low to high.

The first aspect is the appropriateness of the content, this aspect reach mean value is 3.4. It means that the aspect falls into the category of "very good." The second aspect is the appropriateness of the language. This aspect fell into "very good' category by reaching mean value of 3.4. The third aspect was the appropriateness of the presentation. This aspect reached mean value of 3.28 which was into "very good" category. The fourth aspect was the appropriateness of the graphic. This aspect fell into the "good" category by reaching mean value of 3.23. In sum, the evaluation result indicated that the developed material was considered "very good" as it reached the average mean score of 3.3. In addition, there's few comments given such as minor mistakes with spelling and the typing issue. 


\subsection{Limitation of the Research}

Despite the success of the study, it has got some limitations and constraints, too. The main limitation of the research is the absence of the direct involvement of the children who are the most relevant party of the EFH program both during needs analysis stage and implementation stage. Ideally, the children are involved in these two crucial stages. However, because of the covid19 pandemic situation, it was very difficult to do it. One of the ways utilized to fill in this missing pointis that the researchers decided to invite parents' participation as much as possible with the consideration that parents are the ones who know the children best. As a result, parents were involved in this study during both needs analysis and implementation stages.

\section{Conclusion}

An English program, such as English For Holiday (EFH), is concerned with helping children to learn English. In relation to English Education Department of Universitas Ahmad Dahlan, the department has employed an EFH program to help children with English learning during their school break. To accomplish the continuous improvement of the program, it's needed research related to it, as these kinds of research provide meaningful information and a developed product which is important for the improvement of the program's quality.

The research results show that the EFH material is developed to fulfill English children's needs of material for EFH program. The developed product offers an alternative solution to fill the children's needs. Being developed under ADDIE development model, the product evaluation revealed that the developed material is considered very good. Through this material, children participating in EFH program can learn English in an enjoyable way. Although the major target is to improve children's speaking skill, through this material, children can learn and develop their other skills i.e. listening reading and writing as this book is written in integrated way involving all four skills of English.

Referring to the overall evaluation of the developed material, there is one major lack of the whole process of developing it. That's because it doesn't involve the targeted children directly due to the pandemic situation. Consequently, recommendation for further researchers to address this point would be worth contributing.

\section{Acknowledgment}

The authors would like to extend their gratitude to the LPPM (Lembaga Penelitian dan Pengabdian kepada Masyarakat) Universitas Ahmad Dahlan for their support to this research.

\section{Declarations}

Author contribution $\quad$ : The main author carried out the study together with the co-author. Both authors discussed the results of the study and contributed to the final version of the manuscript.

Funding statement $\quad$ : The research is funded by LPPM Universitas Ahmad Dahlan

Conflict of interest $\quad$ : The authors declare no conflict of interest.

Additional information : No additional information is available for this paper.

\section{REFERENCES}

Adams, S., \& Savahl, S. (2017). Nature as children's space: A systematic review. The Journal of Environmental Education, 48(5), 291-321. https://doi.org/10.1080/00958964.2017.1366160

Anghel, B., Cabrales, A., \& Carro, J. M. (2016). Evaluating a bilingual education program in Spain: The impact beyond foreign language learning. Economic Inquiry, 54(2), 1202-1223. https://doi.org/10.1111/ecin.12305 
Bao, R., \& Du, X. (2015). Implementation of task-based language teaching in Chinese as a foreign language: Benefits and challenges. Language, Culture and Curriculum, 28(3), 291-310. https://doi.org/10.1080/07908318.2015.1058392

Bialystok, E. (2018). Bilingual education for young children: review of the effects and consequences. International Journal of Bilingual Education and Bilingualism,21(6), 666-679. https://doi.org/10.1080/13670050.2016.1203859

Brown, H.D. (2004). Language Assessment: Principles and Classroom Practices. New York, US: Pearson Education.

Brown, J. D. (2016). Introducing needs analysis and English for specific purposes. London: Routledge. https://doi.org/10.4324/9781315671390

Brusseau, T. A., Hannon, J., \& Burns, R. (2016). The effect of a comprehensive school physical activity on physical activity and health-related fitness in children from low-income families. Journal of Physical Activity and Health, 13(8), 888-894. https://doi.org/10.1123/jpah.2016-0028

Bus, A. G., Takacs, Z. K., \& Kegel, C. A. (2015). Affordances and limitations of electronic storybooks for young children's emergent literacy. Developmental Review, 35, 79-97. https://doi.org/10.1016/j.dr.2014.12.004

Choeda, Drukpa, P., Yuden, Dukpa, P., \& Chuki, S. (2018). A Guide to Action Research: Enhancing Professional Practice of Teachers in Bhutan. Paro, Bhutan: Royal Education Council.

Collado, S., Corraliza, J. A., Staats, H., \& Ruiz, M. (2015). Effect of frequency and mode of contact with nature on children's self-reported ecological behaviors. Journal of Environmental Psychology, 41, 6573. https://doi.org/10.1016/j.jenvp.2014.11.001

Creswell, J. W. (2012). Educational Research: Planning, Conducting and Evaluating Quantitative and Qualitative Research (4th ed.). Lincoln: Pearson Education.

Creswell, J. W. (2014). Qualitative, Quantitative, and Research Design (4th ed.). Los Angeles: SAGE Publications.

Curle, S. M., \& Derakhshan, A. (2021). Trends in using questionnaires for EMI research: suggestions for future improvements. In Research Methods in English Medium Instruction (pp. 32-45). London: Routledge. https://doi.org/10.4324/9781003025115-3

Garst, B. A., Browne, L. P., \& Bialeschki, M. D. (2011). Youth development and the camp experience. New Directions for Student Leadership, 2011(130), 73-87. https://doi.org/10.1002/yd.398

He, M., Xiang, F., Zeng, Y., Mai, J., Chen, Q., Zhang, J., ... \& Morgan, I. G. (2015). Effect of time spent outdoors at school on the development of myopia among children in China: a randomized clinical trial. Jama, 314(11), 1142-1148. https://doi.org/10.1001/jama.2015.10803

Hutchinson, T., \& Waters, A. (1987). English for Specific Purposes: A learning Centered Approach. Cambridge: Cambridge University Press. https://doi.org/10.1017/CBO9780511733031

Hyland, K. (2019). English for specific purposes: Some influences and impacts. Second handbook of English language teaching, 337-353. https://doi.org/10.1007/978-3-030-02899-2_19

Kendeou, P., McMaster, K. L., \& Christ, T. J. (2016). Reading comprehension: Core components and processes. Policy Insights from the Behavioral and Brain Sciences,3(1), 62-69. https://doi.org/10.1177/2372732215624707

Knezović, A. (2016). Rethinking the languages for specific purposes syllabus in the 21 st century: Topiccentered or skills-centered. International Journal of Information and Communication Engineering, 10(1), 117-132.

Lee, L. C., \& Curran, M. E. (2009). Collaborating with Summer Camps to Prepare Chinese Language Teachers: Linking Theory to Practice. Learning Languages, 15(1), 26-29. 
McCoy, D. C., Yoshikawa, H., Ziol-Guest, K. M., Duncan, G. J., Schindler, H. S., Magnuson, K., ... \& Shonkoff, J. P. (2017). Impacts of early childhood education on medium-and long-term educational outcomes. Educational Researcher, 46(8), 474-487. https://doi.org/10.3102/0013189X17737739

McGriff, S. J. (2000). Instructional System Design (ISD): Using the ADDIE Model. Retrieved from https://www.lib.purdue. edu/sites/default/files/directory/butler38/ADDIE.pdf

Melhuish, E., Ereky-Stevens, K., Petrogiannis, K., Ariescu, A., Penderi, E., Rentzou, K., ... \& Leseman, P. (2015). A review of research on the effects of Early Childhood Education and Care (ECEC) upon child development.

Miles, H., \& Huberman, A. M. (2020). Saldana. (2014). Qualitative data analysis: A methods sourcebook, 3.

Noguchi, J. (2019). ELT: Past, present and future. In Towards a New Paradigm for English Language Teaching (pp. 3-15). London: Routledge. https://doi.org/10.4324/9780429423963-1

Patten, M. (2016). Questionnaire research: A practical guide. London: Routledge. https://doi.org/10.4324/9781315265858

Peraturan Menteri Republik Indonesia Nomor 21 Tahun 2016 Tentang Standar Isi Pendidikan Dasar dan Menengah.

Peraturan Pemerintah Republik Indonesia Nomor 32 Tahun 2013 Tentang Perubahan Atas Peraturan Pemerintah Nomor 19 Tahun 2005 Tentang Standar Nasional Pendidikan.

Rangel Agámez, M. J., \& Pernett Velásquez, J. P. (2020). A topic-based-functional syllabus proposal to promote students' conversation through outdoor games.

Rahman, M. (2015). English for Specific Purposes (ESP): A Holistic Review. Universal Journal of Educational Research, 3(1), 24-31. https://doi.org/10.13189/ujer.2015.030104

Ramírez, C. G. (2015). English for specific purposes: Brief history and definitions. Revista de Lenguas Modernas, (23).

Rugasken, K. \& Harris, J. (2009). English camp: A language immersion program in Thailand: The learning assistance review. Journal of the National College Learning Centre Association, 14(2), 43-51.

Sepúlveda, M. J. E., \& Hutton, R. E. (2019). Shaping summertime experiences: Opportunities to promote healthy development and well-being for children and youth. The National Academies Press. https://doi.org/10.17226/25546

Sholeh, M. B. (2020). Implementation of Task-based Learning in Teaching English in Indonesia: Benefits and Problems. Language Circle: Journal of Language and Literature, 15(1), 1-9. https://doi.org/10.15294/lc.v15i1.26004

Wigfield, A., Gladstone, J. R., \& Turci, L. (2016). Beyond cognition: Reading motivation and reading comprehension. Child development perspectives, 10(3), 190-195. https://doi.org/10.1111/cdep.12184

Wilson, C., \& Sibthorp, J. (2018). Examining the role of summer camps in developing academic and workplace readiness. Journal of Youth Development, 13(1-2), 83-104. https://doi.org/10.5195/JYD.2018.563

Yufrizal, H. (2017). Teachers and students perceptions of communicative competence in English as a foreign language in Indonesia. Educational Research and Reviews, 12(17), 867-883. https://doi.org/10.5897/ERR2017.3243 